\title{
Identifikasi kendala dan Rumusan Strategi Pengelolaan Bank Sampah di Simojawar, Surabaya
}

\author{
Anindya R. Dwicahyani* \\ Jurusan Teknik Industri \\ Institut Teknologi Adhi Tama Surabaya
}

\author{
Eky Novianarenti \\ Jurusan Teknik Mesin \\ Politeknik Perkapalan Negeri Surabaya
}

\author{
Arlini Dyah Radityaningrum \\ Jurusan Teknik Lingkungan \\ Institut Teknologi Adhi Tama Surabaya
}

\author{
Erlinda Ningsih \\ Jurusan Teknik Kimia \\ Institut Teknologi Adhi Tama Surabaya
}

\begin{abstract}
Trash bank is a means for the community to manage waste with economic value. Trash bank has become a new paradigm for the community to be more concerned about the environment. Principally, trash bank management system adopts a simple banking management system. In a trash bank, customers deposit trash, then converted into a balance according to the economic sales value of the deposits. In Surabaya, many regions have initiated and developed trash banks in various scales. One of thos is located in Simojawar, was formed in 2018 is still not running optimally due to various obstacles and problems. Through this research, we aims to identify and analyse the boundaries during the continuation process of the trash bank in Simojawar. In addition, we also propose several strategies that should be carried out to keep the trash bank sustain. Based on observations and interviews with the trash bank employees and customers, in terms of technical, institutional, operational, financial, and management aspects, the trash bank have been going quite well. However, it has not yet given a significant impact to the customers and society. The support and participation of stakeholders including customers, local governments, and collectors' partners are also important for the sustainability of the trash bank. With a good management system, creativity, innovation, and economic prosperity of the society can be improvedcontinuously. The development of Waste Bank management in Simojawar is based on a SWOT analysis through the development of science and technology in administrative management, training for creative products from plastic waste to increase the participation of Simojawar residents to become customers and manage neat and orderly management.
\end{abstract}

Keywords: problems identification, strategy formulation; waste bank; management system.

\begin{abstract}
Abstrak
Bank sampah adalah sebuah sarana bagi masyarakat untuk mengelola sampah yang bernilai ekonomi. Program bank sampah telah menjadi suatu bentuk paradigma baru bagi masyarakat untuk lebih peduli terhadap lingkungan. Pada dasarnya, sistem manajemen bank sampah mengadopsi sistem manajemen perbankan sederhana. Umumnya, para nasabah menyetor sampah kepada bank sampah, kemudian sampah tersebut akan dikonversi menjadi saldo sesuai nilai ekonomis penjualannya. Di Surabaya, bank sampah sudah diinisiasi dan berkembang di berbagai daerah. Salah satunya adalah bank sampah di Simojawar, Kecamatan Jambangan. Bank sampah yang terbentuk pada tahun 2018 ini masih belum berjalan secara maksimal karena berbagai kendala dan masalah. Melalui penelitian ini, hendak dilakukan identifikasi dan analisis kendala selama proses keberlangsungan bank sampah di Simojawar juga dilakukan perumusan strategi yang sebaiknya dilakukan agar bank sampah tetap berkelanjutan. Berdasarkan hasil observasi dan wawancara kepada petugas dan nasabah bank sampah, berdasarkan aspek teknis, aspek operasional kelembagaan, aspek finansial, dan aspek manajemen secara umum sudah berjalan dengan baik. Dampak langsung bank sampah di lingkungan masyarakat Simojawar belum dirasakan secara signifikan oleh para nasabah. Dukungan dan partisipasi dari berbagai pihak seperti masyarakat, pemerintah daerah, dan mitra pengepul juga menjadi faktor penting bagi kerlangsungan bank sampah di Simojawar. Melalui pengelolaan Bank sampah yang baik, kreativitas, inovasi, hingga kesejahteraan ekonomi masyarakat dapat ditingkatkan. Pengembangan pengelolaan Bank Sampah di Simojawar berdasarkan analisis SWOT melalui pengembangan IPTEK dalam managemen pengelolaan administrasi, dan pelatihan produk kreatif dari sampah plastic meningkatkan partisipasi warga untuk menjadi nasabah dan pengelolaan managemen yang rapi dan terat.
\end{abstract}

Kata kunci: identifikasi kendala, formulasi strategi, bank sampah, sistem manajemen 


\section{Pendahuluan}

Permasalahan lingkungan yang bersifat komplek dan sering diremehkan adalah timbunan sampah. Volume sampah semakin bertambah seiring pertambahan jumlah penduduk, selain itu jenis dan karakteristik sampah semakin beragam. Kepedulian Masyarakat terhadap lingkungan didasarkan pada cara berfikir, perilaku, dan kesadaran diri. Dalam menumbuhkan kesadaran masyarakat diperlukan suatu edukasi tentang dampak terhadap kesehatan dan manfaat dari kelestarian lingkungan (Selomo, Birawida, and Mallongi 2016). Edukasi tentang kepedulian terhadap lingkungan ini dapat dilakukan sejak dini,melalui hal yang menyenangkan seperti kegiatan crafting (Novianarenty and Ningsih 2018). Upaya untuk mengurangi masalah sampah diperlukan partisipasi aktif dari warga, yang dapat diawali dari individu, keluarga, dan dapat ditularkan untuk skala besar yaitu masyarakat. Sehingga ada suatu integrasi untuk mengolah sampah seperti adanya bank sampah (Singhirunnusorn, Donlakorn, and Kaewhanin 2017). Pengelolaan sampah yang baik dapat berdampak terhadap lingkungan, kesehatan, sosial, dan ekonomi, serta peran aktif warga untuk mendukung menciptakan lingkungan yang bersih dan sehat.

Penanganan sampah khususnya sampah rumah tangga sudah diatur dalam ketetapan Undang Undang Nomor 18 Tahun 2008 tentang Pengelolaan Sampah, kini perlu perubahan cara pandang masyarakat mengenai sampah dan cara memperlakukan atau mengelola sampah. Adanya ketetapan ini diharapkan dapat mengubah penilaian masyarakat tentang sampah dari yang tak bernilai menjadi suatu yang bernilai (Asteria and Heruman 2016). Penanganan sampah di kalangan masyarakat umumnya masih bersifat komunal seperti membuang sampah ke sungai atau dikumpulkan, dipindahkan, diangkut, dan dibuang ke tempat pembuangan sampah seperti tergambar di Gambar 1. Hal ini dapat menimbulkan dampak negatif bagi lingkungan yaitu mempengaruhi ekosistem tanah dan yang tidak tertangani dengan baik dapat menimbulkan penyakit dari bau yang ditimbulkan (Saputro, Kismartini, and Syafrudin 2015). Sehingga diperlukan suatu solusi untuk pengolahan sampah agar dapat mengubah paradigma masyarakat terhadap sampah.

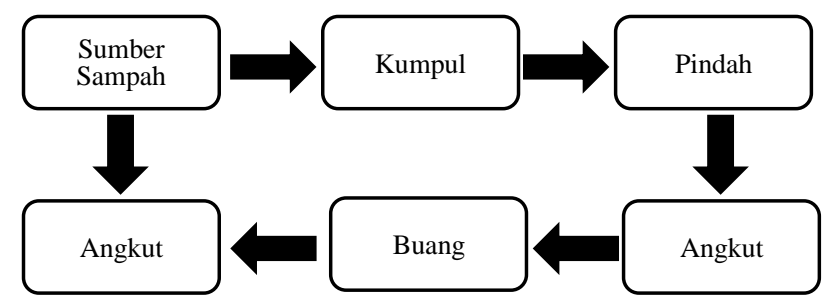

Gambar 1. Alur pembuangan sampah ((Bintarsih Sekarningrum 2017)).

Berdasarkan Peraturan Pemerintah No. 81 Tahun 2012 tentang Pengelolaan Sampah Rumah Tangga dan Sampah Sejenis Sampah Rumah Tangga, maka praktek mengolah dan memanfaatkan sampah harus menjadi langkah nyata dalam mengelola sampah, salah satu strategi pengolahan sampah adalah metode 3R (Reduce, Reuse, Recycle). Namun strategi ini memiliki kendala yaitu kesadaran masyarakat untuk memilah sampah (Wulandari 2014).

Bank sampah merupakan salah satu alternatif untuk pengolahan sampah yang terorganisir dan bernilai ekonomis. Konsep yang digunakan bank sampah ini selayaknyaperbankan pada umumnya. Sebagai nasabah, warga melakukan proses menabung dengan menyerahkan sampah dan membawa buku tabungan. Petugas bank sampah akanmenerima sampah, memilah, dan menimbang. Harga sampah bergantung kepada jenis sampah. Hasil penimbangan kemudian dikonversi menjadi rupiah dan dicatat sebagai saldo dalam buku tabungannasabah (Dhokhikah, Trihadiningrum, and Sunaryo 2015). Untuk meningkatkan pendapatan dan keberlangsungan, bank 
sampah sebaiknya dikelola oleh pengurus yang kreatif, inovatif dan memiliki jiwa kewirausahaan tinggi (Suryani 2014).

Di Surabaya, program bank sampah sangat didukung oleh pemerintah.Hal ini tertuang dalam Peraturan Daerah Kota Surabaya Nomor 5 Tahun 2014 tentang pengelolaan sampah dan kebersihan di kota Surabaya dan Peraturan Walikota Surabaya Nomor 64 Tahun 2018 tentang Kebijakan Strategi Pengelolaan Sampah Rumah Tangga dan Sampah Sejenis Sampah Rumah Tangga. Dengan aturan tersebut, pemilahan sampah harus dilakukan oleh (1) setiap orang pada sumbernya; (2) pengelola kawasan permukiman, kawasan komersial, kawasan industri, kawasan khusus, fasilitas umum, fasilitas sosial, dan fasilitas lainnya; dan (3) pemerintah daerah, pemerintah Surabaya sangat peduli dan konser terhadap sampah (Andina 2019).

Berdasarkan data di lapangan, terdapat satu kawasan di Surabaya yang memiliki bank sampah yang sudah dijadikan percontohan yaitu wilayah di wilayah RW III Kelurahan Jambangan. Keberhasilan bank sampah di Jambangan mampu mengubah paradigma masyakarat dalam kepedulian dan kesadaran terhadap sampah sehingga menghantarkan Kelurahan Jambanganmendapatkan berbagai penghargaan baik tingkat regional dan nasional. Penghargaan tertinggi adalah mendapatkan kalpataru dengan kategori perintis lingkungan dari Presiden Rebublik Indonesia. Keberhasilan ini tidak lepas dari partisipasi warga jambangan yang aktif dalam berbagai hal seperti pengambilan keputusan, keputusan pelaksanaan, pemanfaatan hasil kegiatan pengelolaan bank sampah (Tanuwijaya 2016).Pencapaian yang diraih bank sampah di Jambangan ini memicu pertumbuhan bank sampah di Surabaya, seperti yang tersaji di Tabel 1 (Rosawatiningsih 2019).

Tabel 1. Pertumbuhan Bank Sampah Tahun 2010 - 2017

\begin{tabular}{c|c}
\hline Tahun & Jumlah Bank Sampah \\
\hline 2010 & 15 \\
2011 & 50 \\
2012 & 135 \\
2013 & 180 \\
2014 & 200 \\
2015 & 220 \\
2016 & 260 \\
2017 & 280 \\
\hline
\end{tabular}

Kesuksesan manajemen bank sampah disebabkan oleh beberapa aspek yang sangat berpengaruh, diantaranya aspek kelembagaan, pembiayaan, pengaturan, peran serta masyarakat, dan teknik operasional. Keenam aspek tersebut berkaitan erat satu samalain, sehingga dukungan dan pengelolalaan bank sampah ini bukan suatu kelembagaan yang sederhana karena mencakup aspek teknis, ekonomis dan sosiopolitis (Suryani 2014).

Sebagaisalah satu wilayah padat penduduk di Surabaya, Simojawar telah mendirikan bank sampah pada tahun 2018. Pada awal pendirian terdapat 3 titik penimbangan yaitu di RT2, RT3 dan RT5. Antusias warga Simojawar menjadi nasabah sangat baik. Proses penimbangan berlangsung 1 kali dalam sebulan di pos RT masing-masing. Namun berjalan 2 tahun, pengelolaan bank sampah mulai tidak kondusif, ada 2 titik penimbangan yang mulai tidak aktif. Kendala mulai bermunculan yang dapat menghambat berjalannya bank sampah. Berdasarkan uraian di atas dan observasitim, pengabdian ini dilakukan untuk mengindentifikasi apa yang menjadi kendala yang dialami dalam pengelolaan bank sampah dan merumuskan strategi yang dapat dijalankan dalam rangka peningkatan produktivitas bank sampah di Simojawar. 


\section{Metode Pelaksanaan}

Sasaran dari kegiatan pengabdian ini adalah bank sampah di lingkungan RW 10 Simojawar Surabaya. Kegiatan ini melibatkan para petugas bank sampah, pemerintah setempat (RT 5, RW 10 Simojawar), dan para nasabah bank sampah. Kegiatan pengabdian ini merupakan keberlanjutan dari kegiatan pengabdian yang telah dilakukan sebelumnya, yaitu inisiasi dan pendirian bank sampah di lingkungan RW 10 Simojawar (Novianarenti and Ningsih 2018). Kegiatan ini dilakukan untuk meninjau ulang proses pengelolaan manajemen bank sampah, mengidentifikasi kendala atau hambatan, serta merumuskan strategi yang perlu dilakukan untuk meningkatkan kinerja bank sampah di Simojawar. Secara umum, kerangka pemecahan masalah dan metode pelaksanaan ditunjukkan pada Gambar 2.

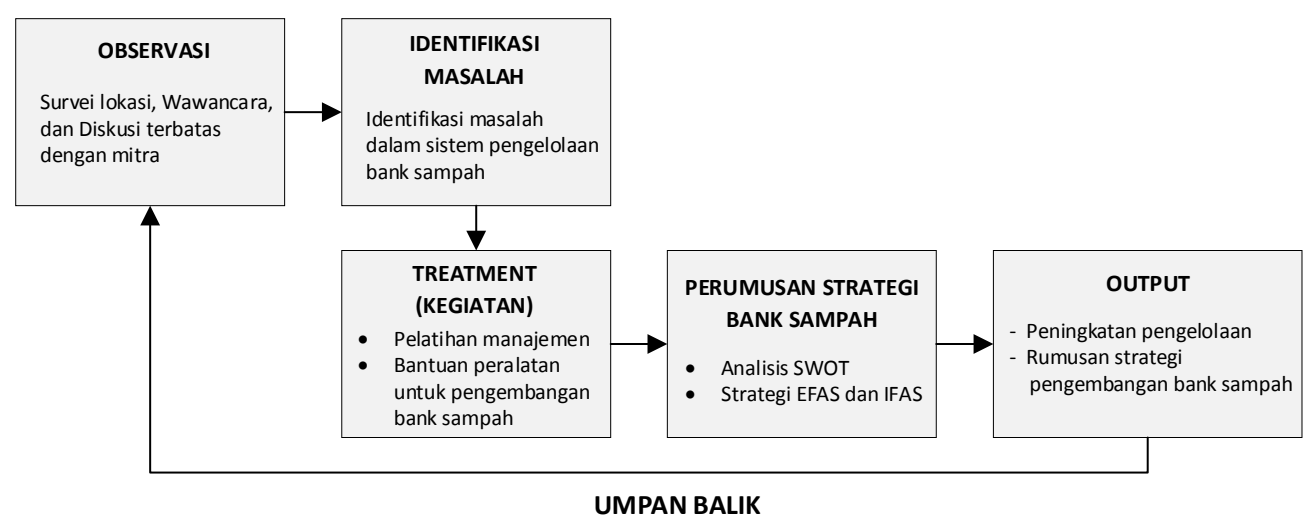

Gambar 2. Tahapan pelaksanaan kegiatan pengabdian.

Langkah pertama yang yang dilakukan adalah memahami situasi masalah dengan observasi, survei lokasi, wawancara, dan diskusi terbatas dengan pihak-pihak yang merupakan pemangku kepentingan (stakeholder) bank sampah yaitu petugas bank sampah, pihak RT dan RW, nasabah, dan pakar. Petugas bank sampah yang terlibat adalah RT 2, RT 3 dan RT 5. Langkah selanjutnya adalah mengidentifikasi dan merumuskan masalah dalam sistem pengelolaan bank sampah. Berdasarkan masalah yang teridentifikasi, kemudian dilakukan perumusan dan pelaksanaan treatment kegiatan yang meliputi: a.) pelatihan manajemen bank sampah; dan b.) bantuan peralatan untuk pengembangan bank sampah. Selain itu, juga dilakukan perumusan strategi pengembangan bank sampah menggunakan metode analisis SWOT, EFAS (External Factor Analysis Strategic), dan IFAS (Internal Factor Analysis Strategic). Output kegiatan pengabdian ini adalah berupa peningkatan di dalam pengelolaan bank sampah dan rumusan strategi pengembangan bank sampah.

\section{Hasil dan Pembahasan}

\section{Gambaran umum permasalahan pengelolaan bank sampah di Simojawar}

Simojawar merupakan salah satu wilayah di Surabaya Barat yang memiliki kepadatan penduduk cukup tinggi, sehinggadaerah tersebut berpeluang besar menghasilkan volume sampah yang tinggi. Bank sampah Simojawar telah terbentuk pada tahun 2018. Namun demikian, pada praktiknya bank sampah ini dihadapkan pada berbagai kendala dan tantangan yang cukup besar karena hampir 50\% warganya berprofesi sebagai pengepul sampah. Selain itu, taraf pendidikan warganya juga rata-rata masih rendah, sehingga sulit untuk mengedukasi warga untuk menjadi nasabah bank sampah. Jika bersedia menjadi nasabah, umumnya motivasi mereka adalah untuk mendapatkan keuntungan ekonomi yang besar. Selain itu, sering terjadi penundaan penjadwalan penimbangan karena kesibukan petugas dan kurangnya sinkronisasi antara petugas bank sampah dengan mitra pengepul dan nasabah. Hal ini secara tidak langsung menimbulkan rasa kecewa dan ketidakpercayaan nasabah kepada bank sampah. Selain itu, perhatian dari pihak pimpinan 
setempat seperti pengurus RT dan RW yang kurang juga turut menjadi tantangan, di manapetugas bank sampah mau tidak mau harus menyelesaikan sendiri setiap permasalahan yang terjadi.

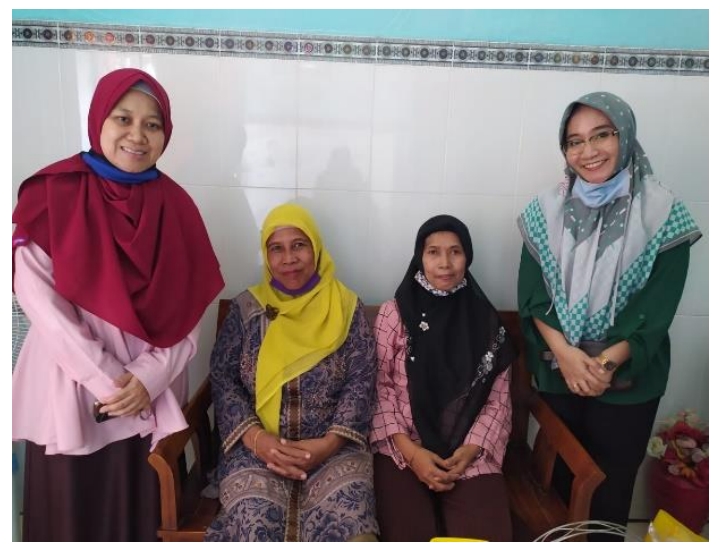

Gambar 3. Wawancara dengan petugas bank sampah.

\section{Pengelolaan Bank Sampah di Simojawar}

Dengan adanya pendirian bank sampah yang telah beroperasi selama 2 tahun memberikan perubahan secara langsung dan tidak langsung kepada para warga Simojawar, Kecamatan Sukomanunggal, Kota Surabaya. Awalnya, warga Simojawarmemandang sampah sebagai suatu hal yang tidak bernilai ekonomi dan tidak ada manfaatnya.Namun sejak adanya bank sampah, warga sedikit demi sedikit mulai tergerak untuk mengumpulkan dan mengelola sampah menjadi suatu hal yang bernilai ekonomi, yaitu melalui bank sampah tersebut. Secara umum, proses pengelolaan bank sampah di Simojawar sesuai dengan pengelolaan bank sampah secara terpadu yang ditunjukkan oleh alur kerja bank sambah pada Gambar 4. Permasalahan yang timbul dalam pengelolaan bank sampah di Simojawar, tidak hanya terbatas pada aspek teknis, namun juga terdapat enam aspek lain yang juga mempengaruhi dan saling berkaitan satu sama lain. Kunci keberhasilan bank sampah terletak pada partisipasi warga sekitar untuk menjadikan pengelolaan bank sampah berjalan dengan baik dan terpadu.

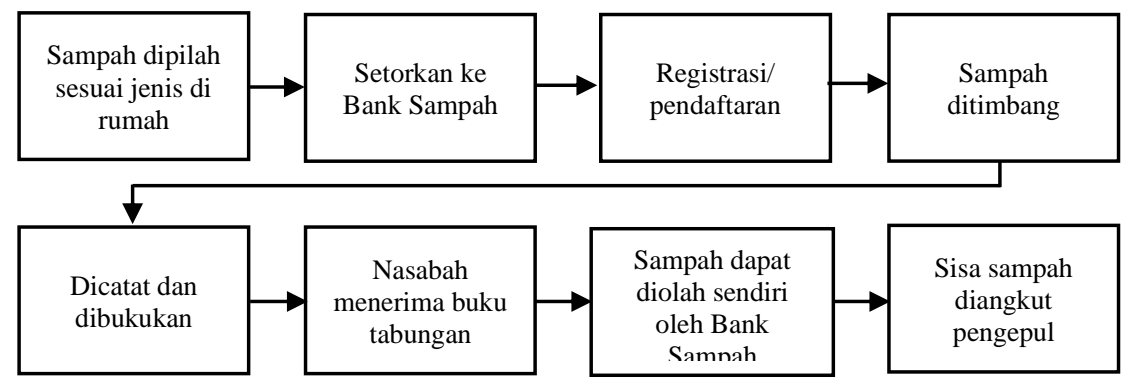

Gambar 4. Alur kerja bank sampah (Suryani 2014).

\section{Faktor-faktor yang Menghambat Pengelolaan Bank Sampah di Simojawar}

Ditinjau dari hasil studi literatur, observasi, dan wawancara, faktor atau kendala yang dialami oleh pengelola bank sampah Simojawar mencakup 5 aspek manajemen persampahan, sebagai berikut:

- Aspek Kelembagaan: Bank sampah Simojawar terbentuk atas inisiatif segelintir warga dan masih belum ada dukungan resmi dari instansi pemerintah, baik tingkat Kelurahan, RW,maupun RT. Sehingga,secara manajemen dan kelembagaan, pengurus bank sampah masih sangat terbatas. Belum tersedianya pembagian tugas dan struktur organisasi yang jelas di antara para pengurus juga menjadi kendala pengelolaan bank sampah. Namun demikian, 
pengurus memiliki semangat dan motivasi untuk memajukan bank sampah di Simojawar, khususnya di RT 5.

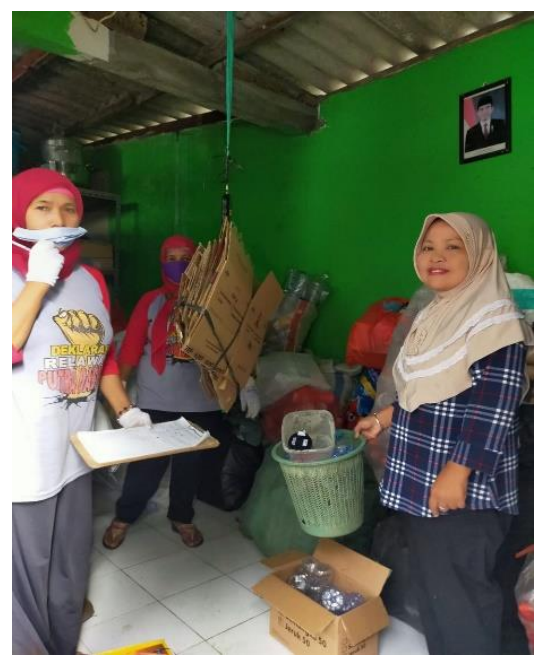

Gambar 4. Penimbangan dan penyimpanan sampah di Bank Sampah Simojawar masih memanfaatkan ruang pos kamling yang sangat terbatas.

- Aspek Pembiayaan: Dalam aspek ini, permasalahan yang dihadapi adalah nilai keuntungan yang masih sangat rendah dikarenakan jumlah nasabah yang sedikit. Selain itu, terkadang nasabah membanding-bandingkan harga sampah per kg nya dengan pengepul yang ada di sekitar Simojawar. Kendala yang lain adalah pengepul terkadang menunda pembayaran hasil penjualan sampah, bahkan hingga 1 bulan. Hal ini menyebabkan petugas bank sampah harus menanggung beban dengan uang pribadi. Sampai saat ini, pembiayaan bank sampah masih swasembada tanpa adanya bantuan pembiayaan dari pihak lain, baik pemerintah maupun swasta. Hal ini menyebabkan bank sampah kesulitan untuk melakukan pengembangan dan perbaikan sistem, seperti pengadaan tempat yang lebih layak dan pengadaan inventaris. Keuntungan bank sampah hanya mampu menutup biaya operasional saja. Bahkan, pengurus bank sampah melakukan operasional bulanan secara sukarela tanpa mendapatkan upah.

- Aspek Pengaturan: Aspek ini berkaitan erat dengan aspek kelembagaan, jika bank sampah ini merupakan suatu lembaga maka perlu adanya sebuah penguatan hukum seperti izin operasi dan struktur organisasi yang jelas. Hal ini menyebabkan proses pengembangan dan kerjasama dengan pihak luar menjadi sulit untuk dilakukan.

- Aspek Peran serta Masyarakat: Bank sampah lahir di tengah masyarakat, oleh masyarakat dan untuk masyarakat. Oleh karena itu, partisipasi warga untuk menyukseskan kegiatan ini adalah faktor yang sangat penting. Selain keuntungan ekonomis, kegiatan pengelolaan bank sampah akan menciptakan zero waste dan lingkungan yang bersih. Diperlukan kesadaran dan kepedulian yang tinggi dari masyarakat dalam rangka pelaksanaanya. Di Bank Sampah Simojawar, minat warga untuk menjadi tenaga dan pegawai masih kurang.Di RT 5 Simojawar, sampai saat ini hanya terdapat 2 pengurus bank sampah. Selain kesadaran, motivasi masyarakat dalam berpartisipasi juga menjadi faktor penentu warga untuk menjadi nasabah. Ada 5 motif yang menjadi dasar warga untuk bergabung menjadi nasabah bank sampah, yang meliputi psikologi, sosial, keagamaan, ekonomi, dan politik. Umumnya, warga Simojawar yang memutuskan bergabung menjadi nasabah bank sampah masih berlandaskan pada motif ekonomi.

- Aspek operasional: Aspek ini sangat penting dan memiliki peran untuk keberlangsungan bank sampah. Sarana dan prasarana yang kurang memadahi di bank sampah Simojawar menjadi poin 
penting yang perlu dibahas oleh banyak pihak. Selama ini, proses penimbangan dan penyimpanan sampah hanya memanfaatkan ruang pos kamling RT 5 yang memiliki keterbatasan tempat dan waktu penyimpanan sampah. Selain sarana, bank sampah juga memiliki masalah mitra pengepul yang masih terbatas jumlahnya dan tidak dapat standby ketika proses penimbangan. Harga pembelian sampah dari pengepul juga sangat fluktuatif. Hal ini menyebabkanbanyak nasabah kerap memprotes harga beli sampah yang terlalu rendah. Inventaris yang berkaitan dengan operasional bank sampah juga menjadi permasalahan.Minimnya keuntungan yang didapatkan dari nasabah menyebabkan pengadaan inventaris tidak dianggarkan.

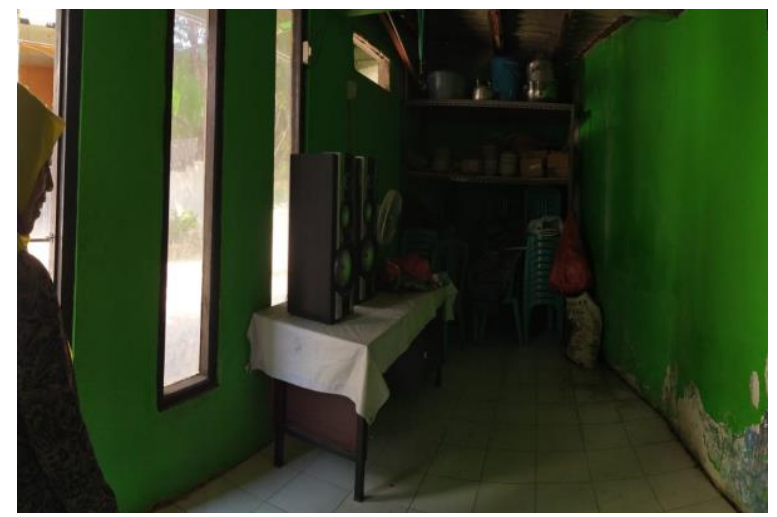

Gambar 5. Lokasi penimbangan dan penyimpanan sampah.

Dari keenam kendala tersebut, dapat ditarik satu permasalahan yang menjadi dasar yaitu dukungan dari pihak pemerintah daerah setempat serta masyarakat sekitar. Jika kedua hal tersebut diperoleh, maka harapannya permasalahan yang terurai menjadi 5 aspek tersebut dapat terselesaikan. Selain 5 aspek kendala yang terindentifikasi di bank sampah Simojawar, beberapa aspek teknis yang teridentifikasi sebagai kendala pengelolaan bank sampah meliputi:

- Pola Pewadahan, banyaknya volume sampah yang didapatkan dari para nasabah dibutuhkan suatu wadah sehingga penyimpanan dan pengangukutan lebih praktis dan rapi.

- Pola Pengumpulan, kedisiplinan para nasabah melakukan penyetoran menyebabkan pengumpulan sampah yang tidak bisa diserahkan langsung kepada pengepul. Sedangkan tempat pengumpulan yaitu pos kamling diharapkan segera bersih kembali.

- Pola Pengangkutan, mitra pengepul yang diajak kerjasama oleh bank sampah hanya satu dan sering kali mitra pengepul sulit dihubungi dan kesibukan (Raharjo, Ihsan, and Yuned 2017).

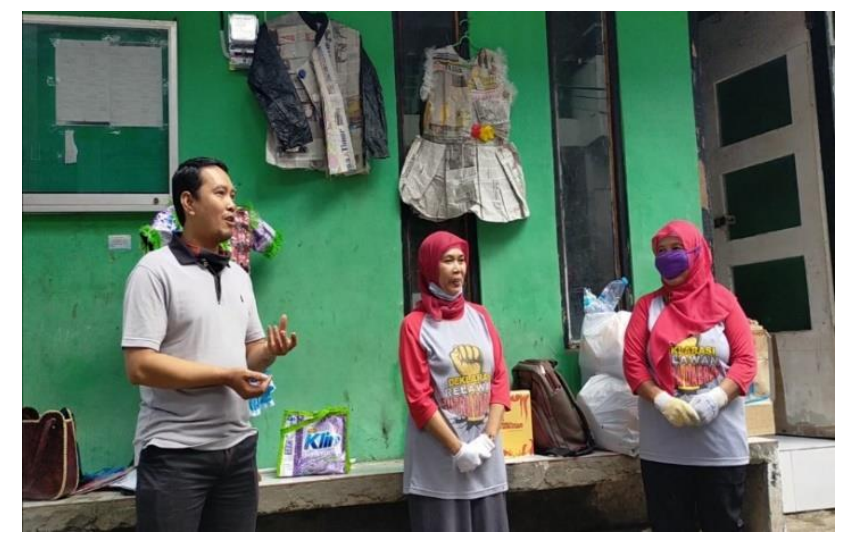

Gambar 6. Dukungan Ketua RT 05 Simojawar dalam kegiatan penimbangan sampah 


\section{Analisis SWOT Bank Sampah Simojawar}

Dalam merumuskan strategi pengembangan bank sampah, digunakan analisis komponen strength, weakness, opportunity dan threat atau dikenal dengan istilah analisis SWOT. Analisis SWOT merupakan alat atau metode yang dapat menggambarkan secara jelas bagaimana faktor internal (IFAS) dapat dimanfaatkan untuk menghadapi faktor eksternal (EFAS). Berdasarakan uraian yang telah dipaparkan, kemudian dapat disusun matriks SWOT dari bank sampah Simojawar seperti ditunjukkan pada Tabel berikut.

Tabel 2. Matriks SWOT Bank Sampah Simojawar.

\begin{tabular}{ll}
\hline \multicolumn{1}{c}{ Kekuatan (Strength) } & IFAS \\
\hline - Jumlah sampah rumah tangga cukup banyak & Kelemahan (Weakness) \\
- Jumlah nasabah bank sampah cukup banyak & - Terbatasnya kas bank sampah \\
- Motivasi petugas bank sampah tinggi & - Belum ada sistem organisasi yang baik \\
- Petugas bank sampah memiliki keterampilan & - Belum memiliki sarana dan prasarana yang \\
pengolahan sampah menjadi produk kreatif & memadai \\
- Sistem administrasi berjalan dengan baik & - Belum ada pelatihan manajerial pengelolaan bank \\
meskipun masih manual & sampah \\
& - Belum ada standar penetapan harga sampah \\
\hline & EFAS \\
\hline & Ancaman (Threat) \\
\hline - Perkembangan IPTEK yang pesat & - Harga beli pengepul yang tidak kompetitif \\
- Dukungan dari pemerintah setempat dan & - Mata pencaharian warga sekitar yang mayoritas \\
akademisi kampus & sebagai pemulung \\
- Terbukanya kerjasama dengan bank sampah & - Rendahnya motivasi warga untuk mengembangkan \\
lain di Surabaya & bank sampah dapat berakibat pada demotivasi \\
- Terbukanya kerjasama dengan LSM & petugas dan nasabah bank sampah \\
lingkungan hidup di Surabaya & - Rendahnya skill petugas bank sampah yang sulit \\
- Program pemerintah Kota Surabaya yang & beradaptasi dengan perkembangan IPTEK \\
berkaitan dengan bank sampah dan & \\
pengolahan sampah & \\
\hline
\end{tabular}

\section{Rumusan Strategi untuk Pengembangan Pengelolaan Bank Sampah di Simojawar}

Berdasarkan uraian situasi, identifikasi kendala, dan analisis SWOT Bank Sampah Simojawar, maka dapat dikembangkan beberapa rumusan strategi untuk pengembangan dan peningkatan sistem pengelolaan bank sampah, antara lain:

1. Dukungan dari pemerintah setempat, team penggerak PKK, Kader Lingkungan, dan masyarakat atau warga sekitar (Sujiyanto 2016). Dengan adanya dukungan minimal dari pihak RW, maka akan banyak warga yang bersedia untuk berpartisipasi dalam bank sampah ini. Sehingga, segala bentuk permasalahan yang timbul dapat diselesaikan secara bersama, di mana warga juga dilibatkan untuk menyelesaikan dan mencari solusi atas permasalahan yang terjadi.

2. Pelatihan atau workshop, pelatihan dan workshop sangat dibutuhkan bagi para petugas bank sampah di Simojawar. Beberapa pelatihan yang dapat dilakukan meliputi pelatihan administrasi dan pencatatan bank sampah, pelatihan pengolahan sampah menjadi produk kreatif dan bernilai ekonomis, hingga pelatihan sistem manajemen bank sampah online berbasis database. Di samping itu, diperlukan studi banding dengan bank sampah lain yang ada di Surabaya yang lebih dulu berdiri dan berhasil untuk sekedar sharing dan berbagi pengalaman. Selain ditujukan ke petugas bank sampah, juga diperlukan sosialisasi yang rutin dilakukan kepada para nasabah dan warga sekitar tentang manfaat dan keuntungan dari adanya bank sampah dan menjadi nasabah. 
3. Memperluas jaringan kerja sama dengan bank sampah, pengepul, dan LSM linkungan hidup di Surabaya, sehingga produktivitas dapat ditingkatkan. Selain itu, dapat dilakukan pengembangan yang dapat menarik minat nasabah seperti penghijauan (tanaman hidroponik atau tanaman toga), pembuatan kompos, hingga pembuatan briket.

\section{Kesimpulan}

Melalui kegiatan pengabdian ini, telah dirumuskan beberapa strategi pengembangan bank sampah berdasarkan lima aspek manajemen persampahan dan hasil analisis SWOT. Strategi pengembangan bank sampah didasarkan pada permasalahan dan kendala yang berhasil teridentifikasi dalam pengelolaan bank sampah di Simojawar, yang meliputi aspek kelembagaan, pembiayaan, pengaturan, peran serta masyarakat, dan operasional. Selain lima faktor tersebut, juga terdapat faktor teknis yang juga menjadi kendala dan menghambat keberlangsungan bank sampah di Simojawar. Strategi yang dapat dilakukan untuk mengatasi kendala serta yang dapat meningkatkan pengelolaan bank sampah di simojawar adalah dukungan dari instansi pemerintah setempat, pelatihan bagi para pengurus bank sampah, dan memperluas kerja sama dengan bank sampah, mitra pengepul, dan stakeholder lain yang terlibat dalam bank sampah. Berdasarkan analisis SWOT,

Rumusan pengembangan pengelolaan Bank Sampah di Simojawar adalah melalui pengembangan IPTEK dalam manajemen pengelolaan administrasi, pelatihan produk kreatif dari sampah plastik, dan dukungan dari pemerintah setempat untuk meningkatkan partisipasi warga Simojawar untuk menjadi nasabah dan pengelolaan managemen yang rapi dan teratur.

\section{Ucapan Terima Kasih}

Pengabdian ini berlangsung atas dukungan dana dari Kementerian Riset dan Teknologi / Badan Riset dan Inovasi Nasional Republik Indonesia melalui Hibah Pengabdian kepada Masyarakat skema Program Kemitraan Masyarakat dengan No. Kontrak: 1/KPM/MONO/LPPM-ITATS/2020 antara Tim Hibah PKM dengan LPPM ITATS, dan No. Kontrak: 105/SP2H/PPM/DRPM/2020 antara LPPM ITATS dengan DRPM LLDIKTI VII. Pengabdian ini juga didukung oleh Yayasan Pendidikan Tinggi Surabaya (YPTS) ITATS, LPPM ITATS, RW 10 Simojawar, RT 5 Simojawar, dan para nasabah.

\section{Daftar Pustaka}

Andina, Elga. 2019. "Analisis Perilaku Pemilahan Sampah Di Kota Surabaya.” Aspirasi: Jurnal Masalahmasalah Sosial.

Asteria, Donna, and Heru Heruman. 2016. "Bank Sampah sebagai Alternatif Strategi Pengelolaan Sampah Berbasis Masyarakat di Tasikmalaya (Bank Sampah (Waste Banks) as an Alternative of CommunityBased Waste Management Strategy in Tasikmalaya)." Jurnal Manusia dan Lingkungan.

Bintarsih Sekarningrum, Desi Yunita dan Sri Sulastri. 2017. "Pengembangan Bank Sampah Pada Masyarakat Di Bantaran Sungai Cikapundung.” Universitas Padjadjaran.

Dhokhikah, Yeny, Yulinah Trihadiningrum, and Sony Sunaryo. 2015. "Community Participation in Household Solid Waste Reduction in Surabaya, Indonesia." Resources, Conservation and Recycling.

Novianarenti, Eky, and Erlinda Ningsih. 2018. "Upaya Peningkatan Nilai Ekonomi Sampah Plastik Dengan Program Bank Sampah Di Simo Jawar Baru Kecamatan Sukomanunggal Surabaya." JPP IPTEK (Jurnal Pengabdian dan Penerapan IPTEK).

Novianarenty, Eky, and Ningsih, Erlinda. 2018. "Pembinaan untuk Menumbuhkan Kepedulian dan Cinta Lingkungan pada Kelompok Belajar Rumah Bangkit di Wilayah Simo Jawar Baru Kecamatan Sukomanunggal Surabaya.” JURNAL Semnas Universitas 17 Agustus Surabaya, 1(1). http://jurnal.untag-sby.ac.id/index.php/semnasuntag/article/view/1696 (November 19, 2020).

Raharjo, Slamet, Taufiq Ihsan, and Sri Rahmiwati Yuned. 2017. "Pengembangan Pengelolaan Sampah Perkotaan Dengan Pola Pemanfaatan Sampah Berbasis Masyarakat." Jurnal Dampak.

Rosawatiningsih, Nila. 2019. "Kebijakan Pengelolaan Ruang Terbuka Hijau (RTH) Taman Flora Surabaya." 
The Journal of Society \& Media.

Saputro, Y. E., Kismartini, and Syafrudin. 2015. "Pengelolaan Sampah Berbasis Masyarakat melalui Bank Sampah." Indonesian Journal of Conservation 4(1): 83-94.

Selomo, Makmur, Agus Bintara Birawida, and Anwar Mallongi. 2016. "Bank Sampah sebagai Salah Satu Solusi Penanganan Sampah di Kota Makassar The Waste Bank Is One of Good Solusion for Handling Waste in Makassar City." jurnal MKMI.

Singhirunnusorn, Wichitra, Kidanun Donlakorn, and Warapon Kaewhanin. 2017. "Household Recycling Behaviours and Attitudes toward Waste Bank Project: Mahasarakham Municipality." Journal of ASIAN Behavioural Studies.

Sujiyanto, S. 2016. “Analisis Pengelolaan Sampah Di Bank Sampah Malang.” Jurnal Ilmu Sosial dan Ilmu Politik Universitas Tribhuwana Tunggadewi.

Suryani, Anih Sri. 2014. "Peran Bank Sampah Dalam Efektivitas Pengelolaan Sampah (Studi Kasus Bank Sampah Malang)." Jurnal Aspirasi.

Tanuwijaya, Fransiska. 2016. "Partisipasi Masyarakat Dalam Pengelolaan Sampah Di Bank Sampah Pitoe Jambangan Kota Surabaya." Kebijakan dan Manajemen Publik.

Wulandari, Fitri. 2014. "Evaluasi Prospek Keberlanjutan Pengelolaan Sampah di Bank Sampah Studi Kasus Bank Sampah di Kota Makassar.” Universitas Gadjah Mada.

\section{Afiliasi:}

Anindya Rachma Dwicahyani"

Jurusan Teknik Industri Institut Teknologi Adhi Tama Surabaya

Jl. Arief Rachman Hakim No. 100, Surabaya

E-mail : anindya.dwicahyani@itats.ac.id

Eky Novianarenti

Jurusan Teknik Mesin Politeknik Perkapalan Negeri Surabaya

Kampus ITS, Jl. Teknik Kimia, Surabaya

E-mail : ekynovianarenti@ppns.ac.id

Arlini Dyah Radityaningrum

Jurusan Teknik Lingkungan Institut Teknologi Adhi Tama Surabaya

Jl. Arief Rachman Hakim No. 100, Surabaya

E-mail :dyah@itats.ac.id

Erlinda Ningsih

Jurusan Teknik Kimia Institut Teknologi Adhi Tama Surabaya

Jl. Arief Rachman Hakim No. 100, Surabaya

E-mail : erlindaningsih84@itats.ac.id 